\title{
SAFETY AND EFFECTS OF CRATAEGUS EXTRACT WS 1442 AND NORDIC WALKING ON LIPID PROFILE AND ENDOTHELIAL FUNCTION: A RANDOMIZED, PARTIALLY BLINDED PILOT STUDY IN OVERWEIGHT VOLUNTEERS
}

\author{
David Niederseer ${ }^{1}$, Eveline Ledl-Kurkowski ${ }^{1}$, Klara Kvita ${ }^{1}$, Petra Funk ${ }^{2}$ and Josef Niebauer ${ }^{1}$ \\ ${ }^{1}$ University Institute of Sports Medicine, Prevention and Rehabilitation, Paracelsus Medical University, \\ Institute of Sports Medicine of the State of Salzburg, Salzburg, Austria; \\ ${ }^{2}$ Clinical Research Department, Dr. Willmar Schwabe GmbH \& Co. KG, Karlsruhe, Germany
}

\begin{abstract}
SUMMARY - Overweight and physical inactivity adversely affect endothelial function and are risk factors for atherosclerosis and cardiovascular disease. Both Crataegus extract WS 1442 and physical exercise exert beneficial effects on endothelial function. We investigated whether WS 1442 and Nordic walking (NW) had comparable effects on endothelial function and lipid profile in overweight subjects. In this partially blinded pilot study, overweight, otherwise healthy volunteers aged 45-75 years were randomized into four groups as follows: WS 1442 2x450 mg/day (WS-standard), WS 1442 2x900 mg/day (WS-double), exercise 2x30 minutes/week (NW-low), and exercise 4x45 minutes/week (NW-high) for 12 weeks. Safety was assessed based on adverse events. Endothelial function testing $\left(\right.$ EndoPAT $\left.^{\bullet}\right)$, assessment of endothelial progenitor cells, lipid profiles, and treadmill testing were performed. Sixty subjects participated in the study. At baseline, subjects in WS-standard/-double groups had higher lipid levels and greater impairment of endothelial function. Subjects with impaired endothelial function showed improvement regardless of the type of intervention. Subjects in WS-standard and WS-double groups showed a trend towards modest decrease in triglycerides and modest increase in HDL-cholesterol; most changes were within the normal limits. In NW-low/-high groups, values also remained within the normal range. Exercise capacity improved in both NW groups. WS-double showed no additional benefits over WS-standard. All adverse events were unrelated or improbably related to treatment. In conclusion, WS 1442 and exercise training were safe and showed beneficial effects on endothelial function and lipid profile in overweight but otherwise healthy volunteers; exercise capacity improved only by Nordic walking.
\end{abstract}

Key words: Crataegus extract WS 1442; Exercise; Overweight; Endothelial progenitor cells

\section{Introduction}

Overweight is among the leading modifiable risk factors for the development of cardiovascular disease

Correspondence to: Josef Niebauer, University Institute of Sports Medicine, Prevention and Rehabilitation, Paracelsus Medical University, Institute of Sports Medicine of the State of Salzburg, Lindhofstraße 20, 5020 Salzburg, Austria

E-mail: j.niebauer@salk.at

Received October 23, 2018, accepted February 8, 2019
(CVD) ${ }^{1}$. Current guidelines recommend weight loss through dietary measures and increased physical activity. While these provisions may suffice in an otherwise healthy population ${ }^{2}$, subjects with relevant comorbidities such as arterial hypertension, diabetes mellitus, or diseases aggravated by overweight may require additional pharmacological treatment.

WS 1442, the active ingredient of the herbal medicinal product Crataegutt ${ }^{\oplus}$ (Dr. Willmar Schwabe 
$\mathrm{GmbH} \&$ Co. KG, Karlsruhe, Germany), is a dry extract from Crataegus leaves with flowers (4-6.6:1), extraction solvent: ethanol $45 \%(\mathrm{w} / \mathrm{w})$. The extract is adjusted to $17.3 \%-20.1 \%$ oligomeric procyanidins and contains flavonoids ${ }^{3}$. WS 1442 has been registered in several European countries as a phytopharmaceutical medicinal product for the treatment of heart failure (HF) (stage II in the New York Heart Association classification), with a recommended daily dose of up to $900 \mathrm{mg}$.

Endothelial dysfunction (ED) is an early marker for the development of CVD that can be detected before the onset of structural changes to the vessel wall ${ }^{4}$. WS 1442 causes vasorelaxation by an endotheliumdependent and nitric oxide-mediated mechanism ${ }^{5,6}$, by supporting endothelium-derived hyperpolarizing factor-mediated vasorelaxation, and by reducing endothelium-dependent contractile responses ${ }^{7}$, and reduces stiffness of the endothelial surface layer ${ }^{8}$. It is assumed that an increased coronary blood flow, reduced ED, inhibition of lipid oxidation and anti-inflammatory properties contribute to its cardioprotective effects 9 Owing to these pharmacological properties ${ }^{6,8}$ and in combination with its favorable safety profile ${ }^{10-12}$, WS 1442 may have beneficial effect on ED and lipid parameters in overweight but otherwise healthy individuals who are at an increased cardiovascular risk (CVR) related to atherosclerosis.

As marketing authorizations for Crataegus extract preparations (including WS 1442) as medicinal products have been granted based on monographs and scientific literature ${ }^{13,14}$, no data on healthy volunteers have been available to date.

Physical exercise has been shown to exert beneficial effects on elevated serum lipids, diabetes mellitus and arterial hypertension. Furthermore, morphological and functional parameters such as endothelial (dys) function may be improved. In a healthy population, increased CVR resulting from overweight may be ameliorated through dietary measures in combination with physical exercise, even when the individual's weight is actually not reduced ${ }^{15-17}$. Physical exercise is therefore an ideal 'control group' to compare the effects of WS 1442 with an intervention already shown to exhibit beneficial effects on ED and lipid metabolism.

We therefore tested two hypotheses; thus, the primary hypothesis of this randomized pilot study was to obtain first information on the safety of two different doses of WS 1442 in overweight but otherwise healthy volunteers. Secondly, we aimed at exploring the effects of WS 1442 on the measures of endothelial function in comparison to physical exercise the benefits of which in maintaining or restoring endothelial function have already been demonstrated ${ }^{15-17}$.

\section{Materials and Methods}

\section{Design}

This was a single-center, randomized, phase I pilot study with four parallel groups comparing two dosages of WS 1442 and two intensities of physical exercise over a period of 12 weeks. Treatments were doubleblind concerning comparison between WS 1442 $900 \mathrm{mg} /$ day and $1,800 \mathrm{mg} /$ day, and open-label for comparison between WS 1442 and physical exercise. Due to the exploratory concept of the trial, no prespecified hypotheses were tested.

\section{Ethics}

The study was performed under consideration of the principles of the Good Clinical Practice and Declaration of Helsinki and registered in clinicaltrials.gov (NCT00982501). The independent ethics committee of the federal State of Salzburg, Austria, reviewed and approved the trial protocol (registration no. 415-E912/14-2008). Informed consent was obtained from all subjects.

\section{Subjects}

Participants were overweight (body mass index, BMI: $25.0-29.9 \mathrm{~kg} / \mathrm{m}^{2}$ ) but otherwise healthy volunteers without regular physical exercise training during the last three months before enrolment. Male and female subjects aged 45-75 years, with blood pressure $\leq 140 / 90 \mathrm{~mm} \mathrm{Hg}$, normal resting electrocardiogram (ECG) and normal ECG stress test were eligible for inclusion. The main exclusion criteria were regular intake of any medication (except for oral contraceptives), echocardiographic evidence of any cardiac disease, $\mathrm{FEV}_{1} / \mathrm{FVC}$ ratio $<70 \%$, clinically important physical or psychiatric diseases, abnormal urinalysis including microalbuminuria, and nicotine consumption. Concomitant intake of other hawthorn preparations or dietary supplements with a potential influence on the study outcome measures was prohibited. 
The study was performed at the Institute of Sports Medicine, Prevention and Rehabilitation of the Paracelsus Medical University in Salzburg, Austria. Advertisements in local newspapers were used for subject recruitment.

\section{Interventions}

WS 1442 was available in film-coated tablets containing $450 \mathrm{mg}$ extract. Treatment group 1 received one WS 1442 tablet and one placebo tablet b.i.d. (WS-standard; total daily dose: $900 \mathrm{mg}$ ), and group 2 received two WS 1442 tablets b.i.d. (WS-double; total daily dose: $1,800 \mathrm{mg}$ ). The tablets were to be taken unchewed in the morning and in the evening with some water. Placebo and WS 1442 tablets were identical in size and appearance.

The subjects in the exercise training did not receive any investigational drugs (including placebo) but practiced Nordic walking (NW) for $2 \times 30$ minutes (group 3, light exercise; NW-low) or for $4 \times 45$ minutes per week (group 4, moderate exercise; NW-high). Eligible subjects were randomized to study groups using an allocation ratio of 1:1:1:1 without further stratification. The random code was generated by a member of the manufacturer's Biometrics Department otherwise not involved in the study, using a validated random number generator (RCODE). Upon randomization, each subject received the lowest available random number. An authorized investigator enrolled the participants. The number was attached to a sealed envelope that included a document showing either the type of exercise or medication number, and concealed the intervention until assignment. After random code assignment, distinction between drug treatment and NW, and between the NW-low and NW-high conditions was open for study participants and investigational staff, whereas distinction between WS-low and WS-high remained double-blind.

The subjects in the exercise training groups had to participate in regular NW workouts guided by instructors. We used NW as exercise intervention due to the well-documented applicability in untrained participants ${ }^{18}$. Subjects received walking poles and a heart rate monitor and were introduced into their use. Exercise training was performed at $>70 \%$ of the maximum heart rate achieved during treadmill test, representing the heart rate corresponding to approximately 3-4 $\mathrm{mmol} / \mathrm{L}$ of blood lactate.

\section{Study schedule}

Screening and baseline examinations were performed to assure the subject eligibility for the trial including medical history assessments, anthropometric measurements, physical status, resting ECG, echocardiography, exercise stress testing ${ }^{19}$, spirometry, and safety laboratory tests including urinalysis. After randomization during the baseline visit, eligible subjects underwent 12-week intervention, with follow-up visits at the end of weeks 6 and 12. Vital signs were assessed at all visits, and laboratory tests were repeated at the final visit. At baseline and during the final visit, treadmill ergometry with lactate testing was performed and endothelial function was assessed. During all visits, adverse events (AEs) were recorded.

\section{Outcomes}

Endothelial function was assessed noninvasively by determining the Reactive Hyperemia Index (RHI) using an Endo-Pat2000 device (Itamar Medical Ltd., Israel). The test is based on endothelium-mediated relaxation of arteries at the distal phalanx of a finger as a reaction to five-minute occlusion of the brachial artery, using a standard blood pressure cuff. RHI is defined as the ratio between the peripheral arterial tone before and after the occlusion. The score is significantly correlated with CVR factors ${ }^{20,21}$ and has been validated as a predictor of cardiovascular outcomes ${ }^{22}$. It has been shown to be sensitive to change induced by treatment $^{23}$. A cut-off value of 1.67 provides $82 \%$ sensitivity and $77 \%$ specificity for diagnosing coronary $\mathrm{ED}^{21}$. The device also computes the Augmentation Index (AI), a measure of arterial stiffness related to age and atherosclerosis ${ }^{24}$.

Treadmill testing was used to determine the $2 \mathrm{mmol} / \mathrm{L}$ and $4 \mathrm{mmol} / \mathrm{L}$ lactate thresholds (aerobic threshold and anaerobic threshold) according to the method described by Heck et al. ${ }^{25}$ and maximum individual performance (heart rate). Participants were instructed to exercise until subjective exhaustion or a systolic blood pressure $\geq 250 \mathrm{~mm} \mathrm{Hg}$ was reached ${ }^{19}$. Treadmill exercise commenced at a speed of $2 \mathrm{~km} / \mathrm{h}$ and slope of $1.5 \%$ and was increased to 4 and $6 \mathrm{~km} / \mathrm{h}$ during the second and third step, respectively. In the fourth step, the slope was increased to $5 \%$, with additional increases by $5 \%$ during each subsequent step. The duration of each step was 3 minutes. Lactate con- 
centrations were determined by blood sampling from the earlobe before the start of treadmill exercise and at the end of each step. Further samples were taken at 1 , 3 and 5 minutes after exercise cessation.

Additionally, quantitative measurement of endothelial progenitor cells (EPCs) related to the progression of CVD due to their role in plaque formation, vasculogenesis, angiogenesis and other pathways ${ }^{26}$ was conducted. Decreased numbers of EPCs were shown to correlate with CVR factors, disease progression and prognosis of coronary artery disease ${ }^{27}$. Peripheral blood mononuclear cells were separated via density gradient centrifugation and incubated with specific antibodies (10 $\mu \mathrm{L}$ per $10^{7}$ cells) as follows: CD3 (fluorescein isothiocyanate; BD Pharmingen), CD34 (phycoerythin; BD Pharmingen), CD45 (peridinin chlorophyll protein; BD Pharmingen) and KDR/anti-VEGFR2 (allophycocyanin, mouse IgG1, R \& D Systems). Acquisition was performed on a FACSCalibur ${ }^{\oplus}$ cytometer (Becton Dickinson, Belgium). Analysis and gating was performed using FlowJo 9.0.1 (Tree Star, Inc., Ashland, OR, USA) software for Macintosh. Lymphocyte population was plotted in a $\mathrm{CD} 45 /$ sideward scatter plot, and CD45+ cells were selected for further analysis. To rule out common lymphocyte populations and to increase the sensitivity for $\mathrm{EPCs}, \mathrm{CD} 3$ positive cells were excluded using a CD45/CD3 plot. The numbers and percentages of triple positive cells for $\mathrm{CD} 45+$, $\mathrm{CD} 34+$ and $\mathrm{KDR}+$ were determined. Altogether, cells positive for $\mathrm{CD} 45+/ \mathrm{CD} 34+/ \mathrm{KDR}+$ and negative for CD3- were defined to be EPCs. To homogenize the sample size, the first $10^{6}$ events were recorded and analyzed. For better visualization of cells with low numbers, logarithmic transformation (log 10) was performed to determine absolute EPC level values ${ }^{28}$.

Lipid profiles of the study subjects were assessed using fasting venous blood samples. Triglycerides, HDL-cholesterol, and total cholesterol were analyzed using Roche/Hitachi Systems (Roche Diagnostics $\mathrm{GmbH}$, Mannheim, Germany); LDL-cholesterol was analyzed using Cobas Integra 400/700/800 for direct measurement of LDL-cholesterol.

\section{Statistics}

In accordance with the concept of the trial as an exploratory pilot study, descriptive statistical analyses were performed and no formal hypotheses were tested.
For outcomes related to ED, missing data at treatment end were replaced by the values obtained at week 6 if available. All analyses were based on all subjects who were randomized and treated.

A total sample size of 60 subjects was planned to obtain at least $4 \times 12$ subjects for ED evaluation. The sample size was chosen to obtain an acceptable precision on summary statistics for the outcomes of interes $^{29}$ for further study planning.

\section{Results}

\section{Study participants}

A detailed and structured telephone interview was carried out with 417 subjects responding to the advertisements. Based on the inclusion and exclusion criteria, we screened 79 subjects and 60 subjects were then randomized (15 per group), whereas 19 did not meet the inclusion criteria or met an exclusion criterion. One subject in the WS-standard group revoked informed consent before the first administration of the investigational treatment and was therefore excluded from all analyses. One subject in each group was withdrawn prematurely during randomized treatment due to an $\mathrm{AE}$; however, all events leading to premature termination were unrelated to the investigational treatments.

All treated subjects were analyzed for safety and pharmacodynamic measures (ED), lipid profile and exercise capacity (Fig. 1).

Table 1 presents baseline characteristics of study subjects. Individual baseline lipid values were either within the applicable reference ranges or considered to be clinically irrelevant. The mean drug compliance was $98.7 \%$ and $97.8 \%$ of tablets taken relative to the prescribed amount for WS-standard and WS-double, respectively. The mean exercise attendance in both NW groups was $93 \%$.

\section{Pharmacodynamic effects}

Regarding endothelial function, subjects randomized to WS 1442 exhibited lower (i.e. less favorable) baseline mean RHI values, and a higher percentage of these subjects were at an increased CVR $(\mathrm{RHI}<1.67)$, as compared with NW-groups. However, the mean baseline augmentation indices were comparable and all treatment groups showed elevated baseline augmentation index mean values. 


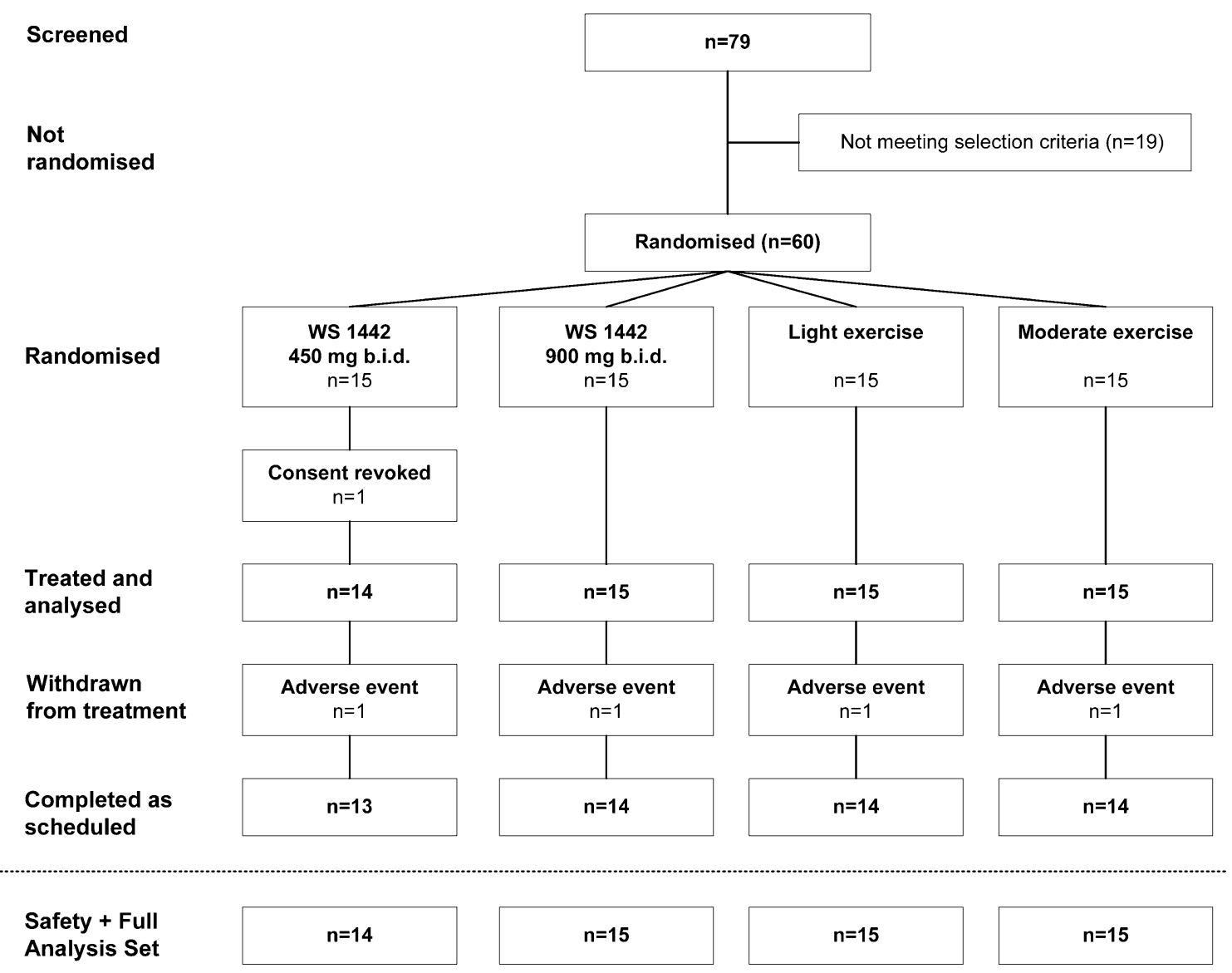

Fig. 1. Distribution of study subjects according to intervention groups.

The numbers of subjects with relevant protocol deviations were 6/14,3/15, 5/15 and 3/15 for WS-standard, WS-double, NWlow and NW-high, respectively. Relevant violations were premature withdrawal during the first 10 weeks of randomized treatment (1/1/1/1 subjects), an inappropriate FEV1/FVC ratio at inclusion (0/1/0/0), non-adherence to the treatment or visit schedule $(0 / 0 / 1 / 1)$, missing pharmacodynamic examinations $(2 / 0 / 1 / 1)$, and use of prohibited concomitant medication $(4 / 1 / 2 / 0)$.

During the study period, subjects in the WS-standard group showed numerical improvements of RHI and AI, whereas all other groups showed deteriorations of the respective parameters (Table 1 ). However, in all groups, subjects with baseline RHI $<1.67$ exhibited mean RHI improvements by $17 \%-22 \%$ as compared to their baseline values. The percentage of subjects with any RHI improvement during randomized treatment was highest in WS-standard group followed by NW-high group. Regarding AI change, the highest percentage of subjects with improvement was recorded in the WS-double group followed by WS-standard group.

At baseline, the number of EPCs was lower in subjects randomized to WS-standard and WS-double (log scale: $0.88 \pm 0.56$ and $0.82 \pm 0.65$ ) compared to
NW-low and NW-high $(0.95 \pm 0.53$ and $0.91 \pm 0.49)$. Subjects receiving WS-standard showed the largest numerical increase of EPC counts by $0.66 \pm 0.74 \mathrm{log}$ units; all other groups exhibited increases by less than 0.4 SD log units.

During treadmill testing (Table 2), the subjects randomized to NW-high showed greatest improvements of all treatment groups, with the mean increase in workload increments versus baseline of $0.6 \pm 0.5$ steps and increase in exercise time of $1.1 \pm 1.4$ minutes. This was accompanied by elevations of the aerobic/anaerobic thresholds regarding both workload increments and exercise time. The subjects randomized to NWlow showed similar but less pronounced effects. In the subjects treated with WS 1442, exercise tolerance remained essentially unchanged. 


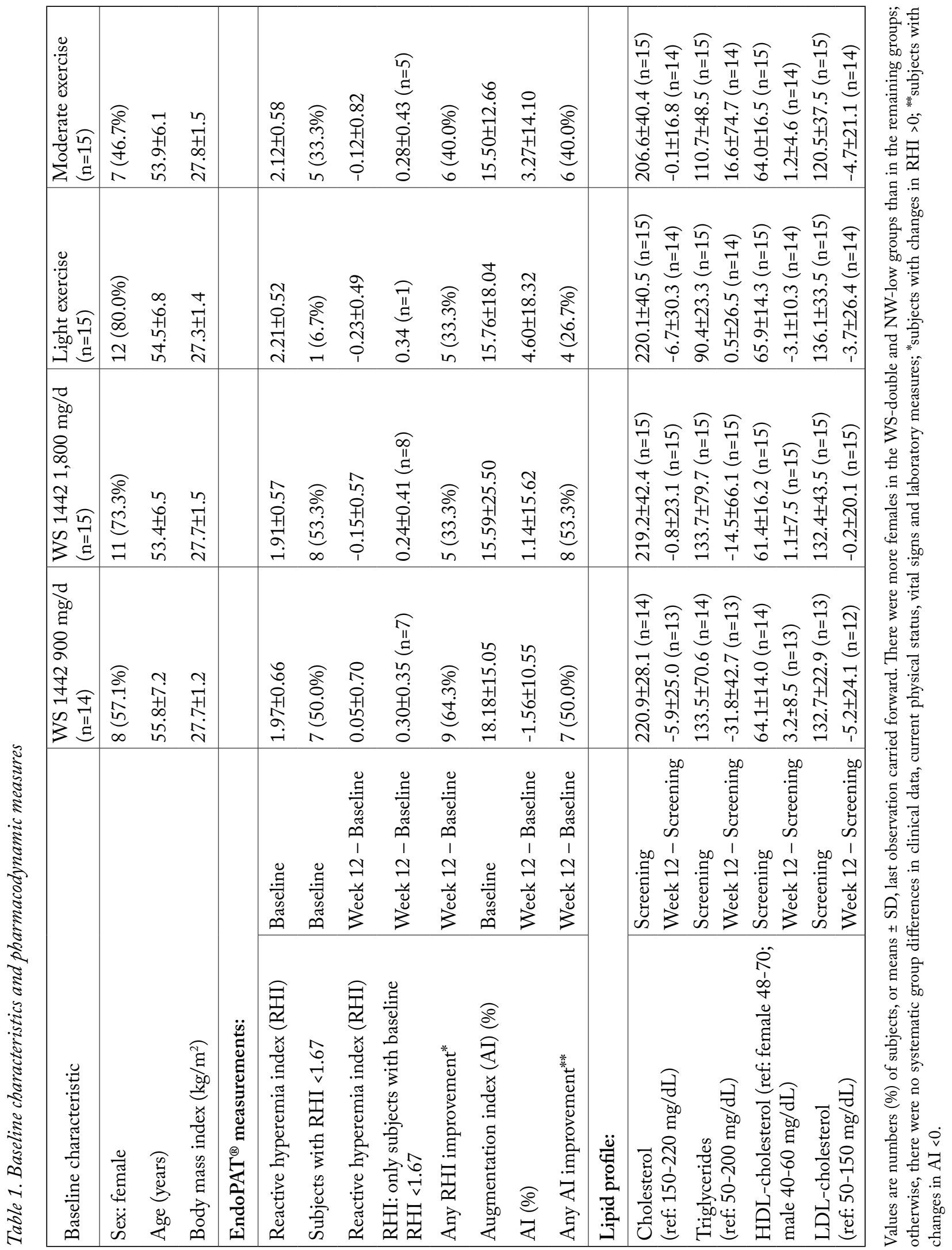


Table 2. Treadmill ergometry test: baseline values and increase from baseline to the end of randomized treatment (values are means $\pm S D$ and subjects with valid test results [n])

\begin{tabular}{|c|c|c|c|c|c|}
\hline & & $\begin{array}{l}\text { WS } 1442 \\
900 \mathrm{mg} / \mathrm{d}\end{array}$ & \begin{tabular}{|l} 
WS 1442 \\
$1,800 \mathrm{mg} / \mathrm{d}$
\end{tabular} & Light exercise & $\begin{array}{l}\text { Moderate } \\
\text { exercise }\end{array}$ \\
\hline Workload increments & & $\begin{array}{l}6.0 \pm 0.9 \\
(\mathrm{n}=14)\end{array}$ & $\begin{array}{l}5.8 \pm 0.8 \\
(\mathrm{n}=15)\end{array}$ & $\begin{array}{l}5.6 \pm 0.9 \\
(\mathrm{n}=15)\end{array}$ & $\begin{array}{l}6.1 \pm 0.6 \\
(n=15)\end{array}$ \\
\hline [increment steps] & Week 12 - Baseline & $\begin{array}{l}0.2 \pm 0.6 \\
(\mathrm{n}=13)\end{array}$ & $\begin{array}{l}0.0 \pm 0.4 \\
(\mathrm{n}=14)\end{array}$ & $\begin{array}{l}0.4 \pm 0.5 \\
(\mathrm{n}=14)\end{array}$ & $\begin{array}{l}0.6 \pm 0.5 \\
(\mathrm{n}=14)\end{array}$ \\
\hline Fxercis time [min] & & $\begin{array}{l}17.0 \pm 2.5 \\
(n=14)\end{array}$ & $\begin{array}{l}15.5 \pm 2.1 \\
(\mathrm{n}=15)\end{array}$ & $\begin{array}{l}15.4 \pm 2.2 \\
(\mathrm{n}=15)\end{array}$ & $\begin{array}{l}17.4 \pm 1.6 \\
(\mathrm{n}=15)\end{array}$ \\
\hline Exercise time [min] & Week 12 - Baseline & $\begin{array}{l}0.1 \pm 1.2 \\
(n=13)\end{array}$ & $\begin{array}{l}-0.1 \pm 1.3 \\
(n=14)\end{array}$ & $\begin{array}{l}0.6 \pm 0.8 \\
(\mathrm{n}=14)\end{array}$ & $\begin{array}{l}1.1 \pm 1.4 \\
(\mathrm{n}=14)\end{array}$ \\
\hline Lactate threshold & Baseline & $\begin{array}{l}3.1 \pm 0.6 \\
(\mathrm{n}=14)\end{array}$ & $\begin{array}{l}2.6 \pm 1.0 \\
(\mathrm{n}=15)\end{array}$ & $\begin{array}{l}2.7 \pm 0.7 \\
(\mathrm{n}=15)\end{array}$ & $\begin{array}{l}3.1 \pm 0.7 \\
(\mathrm{n}=15)\end{array}$ \\
\hline at $2 \mathrm{mmol} / \mathrm{L}$ - workload & Week 12 - Baseline & $\begin{array}{l}0.2 \pm 0.8 \\
(\mathrm{n}=13)\end{array}$ & $\begin{array}{l}0.2 \pm 0.6 \\
(\mathrm{n}=14)\end{array}$ & $\begin{array}{l}0.1 \pm 0.8 \\
(\mathrm{n}=14)\end{array}$ & $\begin{array}{l}0.8 \pm 0.4 \\
(\mathrm{n}=14)\end{array}$ \\
\hline Lactate threshold & Baseline & $\begin{array}{l}4.2 \pm 0.7 \\
(\mathrm{n}=14)\end{array}$ & $\begin{array}{l}3.8 \pm 0.8 \\
(\mathrm{n}=15)\end{array}$ & $\begin{array}{l}3.9 \pm 0.6 \\
(\mathrm{n}=15)\end{array}$ & $\begin{array}{l}4.3 \pm 0.8 \\
(n=15)\end{array}$ \\
\hline at $4 \mathrm{mmol} / \mathrm{L}$ - workload & Week 12 - Baseline & $\begin{array}{l}0.2 \pm 0.7 \\
(\mathrm{n}=13)\end{array}$ & $\begin{array}{l}0.1 \pm 0.5 \\
(\mathrm{n}=14)\end{array}$ & $\begin{array}{l}0.0 \pm 0.4 \\
(\mathrm{n}=14)\end{array}$ & $\begin{array}{l}0.6 \pm 0.5 \\
(\mathrm{n}=14)\end{array}$ \\
\hline
\end{tabular}

Table 3. Adverse events during randomized treatment

\begin{tabular}{|c|c|c|c|c|}
\hline & $\begin{array}{l}\text { WS } 1442 \\
900 \mathrm{mg} / \mathrm{d} \\
(\mathrm{n}=14)\end{array}$ & $\begin{array}{l}\text { WS } 1442 \\
1,800 \mathrm{mg} / \mathrm{d} \\
(\mathrm{n}=15)\end{array}$ & $\begin{array}{l}\text { Light } \\
\text { exercise } \\
(n=15)\end{array}$ & $\begin{array}{l}\text { Moderate } \\
\text { exercise } \\
(n=15)\end{array}$ \\
\hline Number of subjects with any adverse events (\%) & $11(78.6 \%)$ & $12(80.0 \%)$ & $11(73.3 \%)$ & $8(53.3 \%)$ \\
\hline Total number of adverse events & 16 & 24 & 14 & 17 \\
\hline $\begin{array}{l}\text { Causal relationship of adverse events } \\
\text { to study medication: }\end{array}$ & & & & \\
\hline No. of events with no relationship & 14 & 19 & Not applicable & Not applicable \\
\hline No. of events with causal relationship unlikely & 2 & 5 & Not applicable & Not applicable \\
\hline
\end{tabular}

\section{Safety and tolerability}

The percentages of subjects with any AE during the study period were similar in all treatment groups except for NW-low, where fewer participants reported such events (Table 3). Most AEs were symptoms of the musculoskeletal system (e.g., arthralgia, back pain) or trivial infections. Four subjects exposed to WS 1442 had a total of seven events (arthralgia, chest discomfort, diarrhea, forehead headache, abdominal fullness, charley horse and tinnitus), in which a causal relationship with the investigational treatment was considered unlikely; in all other cases, causal relationship was excluded. Four of the seven events with unlikely causal relationship were observed in one patient. One serious
AE was observed in the WS-double group (premature termination of the study to undergo a pre-planned umbilical hernia repair); therefore, causal relationship with the investigational treatment could be excluded. Individual vital signs and safety laboratory measures in all treatment groups were uneventful except for abnormal values that were attributable to concomitant diseases reported as AEs.

During randomized treatment, serum triglycerides decreased within the normal range in subjects receiving WS 1442 but not in NW groups (Table 1). In addition, subjects randomized to WS 1442 showed an increase in HDL-cholesterol that was not seen in the light exercise condition. There was a slight decrease 
within the normal range in LDL-cholesterol in all groups.

\section{Discussion}

This was the first systematic investigation of safety and effects of the Crataegus extract WS 1442 in overweight, otherwise healthy volunteers. Results regarding tolerability and safety of the extract were not indicative of any previously unknown risks associated with the product. They therefore support the favorable safety profile of WS 1442 as previously observed in patients with $\mathrm{HF}^{10-12}$. This applies to the recommended and marketed dose of $900 \mathrm{mg} /$ day, as well as to the double dose of $1,800 \mathrm{mg} /$ day. The study did not show any signal that subjects in WS-double group might be at an appreciably higher risk of AEs than those in WS-standard group. However, the validity of this interpretation is limited by the small sample size of this exploratory pilot study.

The baseline lipid profiles of most study subjects were within the normal limits, and any elevated values were considered to be clinically irrelevant. Participants randomized to WS-standard showed further decreases of triglycerides, which were accompanied by increases in HDL-cholesterol. These observations are consistent with the findings in animal models ${ }^{30}$ and patients with chronic, stable HF of NYHA class III ${ }^{31,32}$. They therefore justify further investigations of the lipid lowering effects of WS 1442. No changes in lipid profiles were observed in NW groups.

All subjects with baseline ED showed an average RHI increase during intervention, whereas the mean RHI remained essentially unchanged throughout the study period in those with normal baseline endothelial function. As more subjects with impaired endothelial function were randomized to WS 1442, the mean RHI increased in these groups to near normal values, whereas RHI in the NW groups was normal already at baseline and remained so throughout the study. The mean EPC counts increased in all study groups throughout the intervention period, with the most pronounced changes observed in the WS-standard group. These results indicated that subjects who were at an increased CVR due to overweight and inactivity, notably those in whom limitations of endothelial function were already measurable, might benefit from treatment with WS 1442 through improvement of im- portant functional markers, including RHI normalization. However, the study did not support an additional benefit of WS 1442 1,800 mg/day over the $900 \mathrm{mg} /$ day dosage in the investigated sample, meaning that we did not find a dose dependent effect of WS 1442. Yet, this finding has to be interpreted with caution because our study was underpowered to answer such a research question. Further adequately powered studies could clarify this interesting issue.

Physical exercise training has been shown to improve $\mathrm{ED}^{15,16,33-35}$. NW was therefore chosen in this study as an active control with proven, well-documented efficacy in the population of interest, in order to obtain an 'anchor' for the effects to be expected from WS 1442 in the same indication. Although it is quite unfortunate that this comparison was affected by coincidental baseline imbalance, our results nevertheless indicated that WS 1442 might induce effects on ED and EPCs similar to those of exercise training ${ }^{17,36}$. This interpretation is, however, only hypothesis-generating and requires confirmation in a larger study.

Unlike WS 1442, NW had beneficial effects on exercise capacity, the most predictive single parameter for cardiovascular events ${ }^{37}$. Therefore, the increase in exercise capacity might be clinically most significant of the changes observed, with the highest impact on CVR. A major problem with the promotion of exercise training is poor long-term compliance ${ }^{38}$. In our study, two of the 30 subjects in the NW groups withdrew from the intervention while all other subjects in these groups (93\%) completed all training sessions and exercised with appropriate heart rates. Compliance was therefore much higher than in the HF-ACTION trial $^{39}$, where $84 \%$ of the patients were compliant during the initial 36 supervised sessions while a decrease to $62 \%$ at one year and to $40 \%$ at three years was documented during subsequent individual home-based training. Poor compliance thus remains a major challenge in the promotion of exercise training.

Except for one subject who revoked the informed consent before the first administration, no other subject in the WS 1442 groups exhibited major treatment compliance problems. Nevertheless, compliance has also been identified as a relevant issue in preventive pharmacotherapy, as demonstrated in the EUROASPIRE trials ${ }^{40}$. Current guidelines and recommendations suggest physical exercise training and dietary measures in otherwise healthy individuals who 
are overweight but not obese, whereas pharmacological treatment is only recommended if comorbidities are already present ${ }^{2,41}$. Individuals at risk of CVD may nevertheless prefer a drug over lifestyle modification, or they may not be able to exercise due to physical disability. In such cases, WS 1442 may be a viable option if a prophylactic and therapeutic effect on endothelial function can be confirmed in this population.

The main limitation of our study was the small sample size. It is the nature of a pilot study that it is only hypothesis-generating and does not provide definite answer to the research question proposed.

The results of this pilot study indicated that Crataegus extract WS 1442 might have a beneficial effect on the lipid profile and endothelial function, similar to the effects of regular exercise training, and without signals of unwanted effects. Nonetheless, beneficial changes in exercise capacity could only be achieved through exercise training. Although the results of this small-sample pilot study should be interpreted cautiously and the comparison between WS 1442 and NW may have been biased by coincidental baseline imbalance, it may nevertheless be worthwhile to further investigate the potential of the extract as a preventive tool in the armamentarium against the development of CVD in overweight, inactive, yet otherwise healthy individuals.

\section{Acknowledgments}

We thank all the volunteers who participated in this study. The study including medical writing services for the manuscript was supported by Dr. Willmar Schwabe GmbH \& Co. KG. We are grateful to Dr. Andreas Völp, Psy Consult, Frankfurt (Germany) for medical writing services.

\section{References}

1. Erbel R, Möhlenkamp S, Jöckel KH, Lehmann N, Moebus S, Hoffmann B, Schmermund A, Stang A, Siegrist J, Dragano N, Grönemeyer D, Seibel R, Mann K, Bröcker-Preuss M, Kröger K, Volbracht L. Cardiovascular risk factors and signs of subclinical atherosclerosis in the Heinz Nixdorf Recall Study. Dtsch Arztebl Int. 2008;105(1-2):1-8. DOI: 10.3238/arztebl.2008.0001

2. Tsigos C, Hainer V, Basdevant A, Finer N, Fried M, MathusVliegen E, Micic D, Maislos M, Roman G, Schutz Y, Toplak H, Zahorska-Markiewicz B, Obesity Management Task Force of the European Association for the Study of O. Management of obesity in adults: European clinical practice guidelines. Obesity Facts. 2008;1(2):106-16. DOI: 10.1159/000126822

3. Busse WR, Juretzek W, Koch E. Hawthorn (Crataegus). In: Coates P, Blackman MR, Cragg G, Levine M, Moss J, White J, editors. Encylopedia of Dietary Supplements. New York: Marcel Dekker, 2005; p. 337-47.

4. Davignon J, Ganz P. Role of endothelial dysfunction in atherosclerosis. Circulation. 2004;109(23 Suppl 1):III27-32. DOI: 10.1161/01.CIR.0000131515.03336.f8

5. Anselm E, Socorro VF, Dal-Ros S, Schott C, Bronner C, Schini-Kerth VB. Crataegus special extract WS 1442 causes endothelium-dependent relaxation via a redox-sensitive Src- and Akt-dependent activation of endothelial NO synthase but not via activation of estrogen receptors. J Cardiovasc Pharmacol. 2009;53(3):253-60. DOI: 10.1097/FJC.0b013e31819ccfc9

6. Brixius K, Willms S, Napp A, Tossios P, Ladage D, Bloch W, Mehlhorn U, Schwinger RH. Crataegus special extract WS 1442 induces an endothelium-dependent, NO-mediated vasorelaxation via eNOS-phosphorylation at serine 1177. Cardiovasc Drugs Ther. 2006;20(3):177-84. DOI: 10.1007/s10557006-8723-7

7. Idris-Khodja N, Auger C, Koch E, Schini-Kerth VB. Crataegus special extract $\mathrm{WS}^{\circ} 1442$ prevents aging-related endothelial dysfunction. Phytomedicine. 2012;19(8-9):699-706. DOI: 10.1016/j.phymed.2012.04.005

8. Peters W, Druppel V, Kusche-Vihrog K, Schubert C, Oberleithner H. Nanomechanics and sodium permeability of endothelial surface layer modulated by hawthorn extract WS 1442 . PloS One. 2012;7(1):e29972. DOI: 10.1371/journal.pone. 0029972

9. Chatterjee SS, Koch E, Jaggy H, Krzeminski T. In-vitro- und In-vivo-Untersuchungen zur kardioprotektiven Wirkung von oligomeren Procyanidinen in einem Crataegus-Extrakt aus Blättern mit Blüten. Arzneimittelforschung. 1997;47(7):821-5. (in German)

10. Daniele C, Mazzanti G, Pittler MH, Ernst E. Adverse-event profile of Crataegus spp.: a systematic review. Drug Saf. 2006; 29(6):523-35. DOI: 10.2165/00002018-200629060-00005

11. Tassell MC, Kingston R, Gilroy D, Lehane M, Furey A. Hawthorn (Crataegus spp.) in the treatment of cardiovascular disease. Pharmacogn Rev. 2010;4(7):32-41. DOI: 10.4103/ 0973-7847.65324

12. Holubarsch CJ, Colucci WS, Meinertz T, Gaus W, Tendera M. The efficacy and safety of Crataegus extract WS 1442 in patients with heart failure: the SPICE trial. Eur J Heart Fail. 2008;10(12):1255-63. DOI: 10.1016/j.ejheart.2008.10.004

13. European Scientific Cooperative on Phytotherapy. (2003) Crataegi folium com flore - Hawthorn leaf and flower. In: ESCOP Monographs. $2^{\text {nd }}$ edn. Stuttgart: Thieme, 2003; p. 98-106.

14. European Parliament and Council. Directive 2004/24/EC of the European Parliament and of the Council of 31 March 2004 amending, as regards traditional herbal medicinal products. Official Journal of the European Union. 2004;L136/185L136/190. 
15. Sixt S, Beer S, Bluher M, Korff N, Peschel T, Sonnabend M, Teupser D, Thiery J, Adams V, Schuler G, Niebauer J. Longbut not short-term multifactorial intervention with focus on exercise training improves coronary endothelial dysfunction in diabetes mellitus type 2 and coronary artery disease. Eur Heart J. 2010;31(1):112-9. DOI: 10.1093/eurheartj/ehp398

16. Desch S, Sonnabend M, Niebauer J, Sixt S, Sareban M, Eitel I, de Waha S, Thiele H, Bluher M, Schuler G. Effects of physical exercise versus rosiglitazone on endothelial function in coronary artery disease patients with prediabetes. Diabetes Obes Metab. 2010;12(9):825-8. DOI: 10.1111/j.1463-1326.2010. 01234.x

17. Hambrecht R, Wolf A, Gielen S, Linke A, Hofer J, Erbs S, Schoene N, Schuler G. Effect of exercise on coronary endothelial function in patients with coronary artery disease. $\mathrm{N}$ Engl J Med. 2000;342(7):454-60. DOI: 10.1056/NEJM200002173 420702

18. Tschentscher M, Niederseer D, Niebauer J. Health benefits of Nordic walking: a systematic review. Am J Prev Med. 2013; 44(1):76-84. DOI: 10.1016/j.amepre.2012.09.043

19. Fox K, Garcia MA, Ardissino D, Buszman P, Camici PG, Crea F, Daly C, De Backer G, Hjemdahl P, Lopez-Sendon J, Marco J, Morais J, Pepper J, Sechtem U, Simoons M, Thygesen K, Priori SG, Blanc JJ, Budaj A, Camm J, Dean V, Deckers J, Dickstein K, Lekakis J, McGregor K, Metra M, Osterspey A, Tamargo J, Zamorano JL. Guidelines on the management of stable angina pectoris: executive summary: the Task Force on the Management of Stable Angina Pectoris of the European Society of Cardiology. Eur Heart J. 2006;27(11):1341-81. DOI: 10.1093/eurheartj/ehl001

20. Hamburg NM, Keyes MJ, Larson MG, Vasan RS, Schnabel R, Pryde MM, Mitchell GF, Sheffy J, Vita JA, Benjamin EJ. Cross-sectional relations of digital vascular function to cardiovascular risk factors in the Framingham Heart Study. Circulation. 2008;117(19):2467-74. DOI: 10.1161/CIRCULATIONAHA.107.748574

21. Bonetti PO, Pumper GM, Higano ST, Holmes DR Jr, Kuvin JT, Lerman A. Noninvasive identification of patients with early coronary atherosclerosis by assessment of digital reactive hyperemia. J Am Coll Cardiol. 2004;44(11):2137-41. DOI: 10.1016/j.jacc.2004.08.062

22. Rubinshtein R, Kuvin JT, Soffler M, Lennon RJ, Lavi S, Nelson RE, Pumper GM, Lerman LO, Lerman A. Assessment of endothelial function by non-invasive peripheral arterial tonometry predicts late cardiovascular adverse events. Eur Heart J. 2010;31(9):1142-8. DOI: 10.1093/eurheartj/ehq010

23. Aversa A, Vitale C, Volterrani M, Fabbri A, Spera G, Fini M, Rosano GM. Chronic administration of sildenafil improves markers of endothelial function in men with type 2 diabetes. Diabet Med. 2008;25(1):37-44. DOI: 10.1111/j.1464-5491. 2007.02298.x

24. Kuvin JT, Patel AR, Sliney KA, Pandian NG, Sheffy J, Schnall RP, Karas RH, Udelson JE. Assessment of peripheral vascular endothelial function with finger arterial pulse wave amplitude.
Am Heart J. 2003;146(1):168-74. DOI: 10.1016/S00028703(03)00094-2

25. Heck H, Hess G, Mader A. Vergleichende Untersuchung zu verschiedenen Laktat-Schwellenkonzepten. Dtsch Z Sportmed. 1985;36(1):19-25. (in German)

26. Asahara T, Murohara T, Sullivan A, Silver M, van der Zee R, Li T, Witzenbichler B, Schatteman G, Isner JM. Isolation of putative progenitor endothelial cells for angiogenesis. Science. 1997;275(5302):964-7. DOI: 10.1126/science.275.5302.964

27. Vasa M, Fichtlscherer S, Aicher A, Adler K, Urbich C, Martin $\mathrm{H}$, Zeiher AM, Dimmeler S. Number and migratory activity of circulating endothelial progenitor cells inversely correlate with risk factors for coronary artery disease. Circ Res. 2001;89(1): E1-7. DOI: 10.1161/hh1301.093953

28. Brunk CF, Bohman RE, Brunk CA. Conversion of linear histogram flow cytometry data to a logarithmic display. Cytometry. 1982;3(2):138-41. DOI: 10.1002/cyto.990030213

29. Julious SA. Sample size of 12 per group rule of thumb for a pilot study. Pharm Stat. 2005;4(4):287-91.

30. Kausar S, Zaheer Z, Saqib M, Zia B. The effect of crataegus (hawthorn) extract alone and in combination with simvastatin on serum lipid profile in hyperlipidemic albino rats. Biomedica. 2011;27(2):140-7.

31. Tauchert M. Efficacy and safety of crataegus extract WS 1442 in comparison with placebo in patients with chronic stable New York Heart Association class-III heart failure. Am Heart J. 2002;143(5):910-5. DOI: 10.1067/mhj.2002.121463

32. Tauchert M, Meng G, Kieser M, Köhler S. Nachweis der klinischen Wirksamkeit und Verträglichkeit einer Therapie mit der Kombination Crataegus-Spezialextrakt WS 1442900 mg bzw. $1800 \mathrm{mg}$ und Triamteren $50 \mathrm{mg}$-Hydrochlorothiazid 25 $\mathrm{mg}$ im Vergleich zu Placebo und Triamteren $50 \mathrm{mg}$-Hydrochlorothiazid $25 \mathrm{mg}$ bei Patienten mit Herzinsuffizienz NYHA III. Unpublished internal report. Dr. Willmar Schwabe GmbH \& Co. KG, Karlsruhe, 2001. (in German)

33. European Association of Cardiovascular Prevention, Rehabilitation Committee for Science Guidelines, EACPR, Corra U, Piepoli MF, Carre F, Heuschmann P, Hoffmann U, Verschuren M, Halcox J, Document R, Giannuzzi P, Saner H, Wood D, Piepoli MF, Corra U, Benzer W, Bjarnason-Wehrens B, Dendale P, Gaita D, McGee H, Mendes M, Niebauer J, Zwisler $\mathrm{AD}$, Schmid JP. Secondary prevention through cardiac rehabilitation: physical activity counselling and exercise training: key components of the position paper from the Cardiac Rehabilitation Section of the European Association of Cardiovascular Prevention and Rehabilitation. Eur Heart J. 2010;31 (16):1967-74. DOI: 10.1093/eurheartj/ehq236

34. Thompson PD, Buchner D, Pina IL, Balady GJ, Williams MA, Marcus BH, Berra K, Blair SN, Costa F, Franklin B, Fletcher GF, Gordon NF, Pate RR, Rodriguez BL, Yancey AK, Wenger NK, American Heart Association Council on Clinical Cardiology Subcommittee on Exercise, Rehabilitation, and Prevention, American Heart Association Council on Nutrition, Physical 
Activity, and Metabolism Subcommittee on Physical Activity. Exercise and physical activity in the prevention and treatment of atherosclerotic cardiovascular disease: a statement from the Council on Clinical Cardiology (Subcommittee on Exercise, Rehabilitation, and Prevention) and the Council on Nutrition, Physical Activity, and Metabolism (Subcommittee on Physical Activity). Circulation. 2003;107(24):3109-16. DOI: 10.1161/ 01.CIR.0000075572.40158.77

35. Niebauer J. Exercise training in diabetes mellitus: an efficient but underused therapeutic option in prevention and treatment of coronary artery disease. In: Perk J, Mathes P, Gohlke H, et al., editors. Cardiovascular Prevention and Rehabilitation. London: Springer, 2007; p. 138-41.

36. Mayr M, Niederseer D, Niebauer J. From bench to bedside: what physicians need to know about endothelial progenitor cells. Am J Med. 2011;124(6):489-97. DOI: 10.1016/j.amjmed.2011.01.015

37. Myers J, Prakash M, Froelicher V, Do D, Partington S, Atwood JE. Exercise capacity and mortality among men referred for exercise testing. N Engl J Med. 2002;346(11):793-801. DOI: 10.1056/NEJMoa011858
38. Schuler G, Adams V, Goto Y. Role of exercise in the prevention of cardiovascular disease: results, mechanisms, and new perspectives. Eur Heart J. 2013;34(24):1790-9. DOI: 10.1093/ eurheartj/eht111

39. O'Connor CM, Whellan DJ, Lee KL, Keteyian SJ, Cooper LS, Ellis SJ, Leifer ES, Kraus WE, Kitzman DW, Blumenthal JA, Rendall DS, Miller NH, Fleg JL, Schulman KA, McKelvie RS, Zannad F, Pina IL. Efficacy and safety of exercise training in patients with chronic heart failure: HF-ACTION randomized controlled trial.JAMA. 2009;301(14):1439-50. DOI: 10.1001/ jama.2009.454

40. Kotseva K, Wood D, De Backer G, De Bacquer D, Pyorala K, Keil U. Cardiovascular prevention guidelines in daily practice: a comparison of EUROASPIRE I, II, and III surveys in eight European countries. Lancet. 2009;373(9667):929-40. DOI: 10.1097/00004872-200310000-00009

41. Makarovic Z, Makarovic S, Bilic-Curcic I, Mihaljevic I, Mlinarevic D. Nonobstructive coronary artery disease - clinical relevance, diagnosis, management and proposal of a new pathophysiological classification. Acta Clin Croat. 2018;57(3): 528-41. 10.20471/acc.2018.57.03.17

\section{Sažetak \\ NEŠKODLJIVOST I DJELOTVORNOST GLOGOVA EKSTRAKTA WS 1442 I NORDIJSKOG HODANJA NA PROFIL LIPIDA I FUNKCIJU ENDOTELA: RANDOMIZIRANO, DJELOMICE SLIJEPO PROBNO ISTRAŽIVANJE U DOBROVOLJACA PREKOMJERNE TJELESNE TEŽINE}

\section{Niederseer, E. Ledl-Kurkowski, K. Kvita, P. Funk i J. Niebauer}

Prekomjerna težina i tjelesna neaktivnost štetno djeluju na funkciju endotela i predstavljaju rizične čimbenike za aterosklerozu i srčanožilne bolesti. Glogov ekstrakt WS 1442 i tjelesna aktivnost oboje utječu povoljno na endotelnu funkciju. Ispitivali smo imaju li WS 1442 i nordijsko hodanje (NH) usporedive učinke na endotelnu funkciju i profil lipida u osoba prekomjerne tjelesne težine. U ovom djelomice slijepom probnom istraživanju su inače zdravi dobrovoljci prekomjerne tjelesne težine u dobi od 45 do 75 godina nasumce podijeljeni u četiri skupine: WS 1442 2x450 mg/dan (standardna doza WS), WS $14422 \times 900 \mathrm{mg} /$ dan (dvostruka doza WS), tjelovježba 2x30 minuta na tjedan (niska razina NH) i tjelovježba 4x45 minuta na tjedan (visoka razina NH) kroz 12 tjedana. Neškodljivost se procjenjivala na osnovi štetnih događaja. Provedeno je testiranje endotelne funkcije (EndoPAT ${ }^{\oplus}$ ), procjena endotelnih progenitorskih stanica, profila lipida te test opterećenja. U istraživanju je sudjelovalo 60 ispitanika. Ispitanici na standardnoj/dvostrukoj dozi WS imali su bazalno više razine lipida i veći poremećaj endotelne funkcije. Ispitanici s poremećenom endotelnom funkcijom pokazali su poboljšanje bez obzira na vrstu intervencije. Ispitanici na standardnoj i dvostrukoj dozi WS pokazivali su tendenciju ka skromnom sniženju triglicerida i skromnom porastu HDL-kolesterola; većina ovih promjena bila je unutar normalnih granica. Uz nisku/visoku razinu $\mathrm{NH}$ vrijednosti su također ostale unutar normalnog raspona. Sposobnost za tjelovježbu poboljšala se u objema skupinama NH. Dvostruka razina WS nije pokazala dodatnih koristi u usporedbi sa standardnom dozom WS. Svi štetni događaji bili su nevezani ili malo vjerojatno povezani s tretmanom. U zaključku, WS 1442 i tjelovježba pokazali su se neškodljivima i imali su povoljan učinak na funkciju endotela i profil lipida kod inače zdravih osoba prekomjerne tjelesne težine; sposobnost za tjelovježbu poboljšala se samo pomoću NH.

Ključne riječi: Glogov ekstrakt WS 1442; Vježbanje; Prekomjerna tjelesna težina; Endotelne progenitorske stanice 